JURNAL TERKNOSAINS

VOLUME 3

No. 1, 22 Desember 2013

Halaman 1-80

\title{
UJI BIOKOMPATIBILITAS KOMPOSIT POLIVINIL ALKOHOL- HIDROKSIAPATIT DENGAN PENGUAT CATGUT SEBAGAI BAHAN PENYAMBUNG PATAH TULANG
}

\author{
M. Taha Ma'ruf \\ Bagian Ilmu Bedah Mulut, Fakultas Kedokteran Gigi \\ Universitas Mahasaraswati Denpasar-Bali \\ Email: tahamaaruf@gmail.com. \\ Widowati Siswomihardjo \\ Bagian Biomaterial, Fakultas Kedokteran Gigi \\ Universitas Gadjah Mada Yogyakarta \\ Email: bundi.kunto@gmail.com. \\ Marsetyawan HNE Soesatyo \\ Bagian Histologi dan Biologi Sel, Fakultas Kedokteran \\ Universitas Gadjah Mada Yogyakarta \\ Email: marshnes@yahoo.com. \\ Alva Edy Tontowi \\ Jurusan Teknik Mesin \& Industri, Fakultas Teknik \\ Universitas Gadjah Mada Yogyakarta \\ Email: alvaedytontowi@ugm.ac.id.
}

\begin{abstract}
Bone fracture fixation device have been using rigid metallic materials such as titanium, titanium - alloy or cobalt chrome. Besides having some advantages, as the titanium fixation devices also have disadvantages such as strength and stiffness is too high, continuously stimulate the bone causing bone atrophy under the plate, further disrupting the growth of bones, especially in children. Another deficiency of this metal material is sensitive to temperature changes and the spread of metal ions in several organs. Some of these shor tcomings led to the need for a secondary operation. Bone fracture fixation device can be absorbed by the body such as the poly-l-lactic acid (PLLA) as well as show some advantages, it also has some drawbacks due to the high crystalline products during the degradation process. Lactic acid monomer released after degradation cause of cellular response at the implant site, which facilitates the release of chemical mediators such as prostaglandine by fibroblasts and macrophages as a cause of bone resorption. Therefore, in this study wanted to develop the use of other polymeric materials have good biocompatibility and mechanical strength appropriate to have a bone fracture fixation devices that can be absorbed by the body, such as Polyvinyl Alcohol (PVA). Previous research suggests that the PVA - HA composite with catgut reinforced has sufficient and stable mechanical strength as bone fracture fixation material. The purpose of this study is to know whether the PVA-HA composite with catgut reinforced has good biocompatibility without toxicity and hypersensitivity effects in experimental animals.
\end{abstract}


Biocompatibility testing include local cytotoxicity and type IV contact hypersensitivity test. This type of research is experimental in vivo laboratory using wistar rats (Rattus norvegicus). Testing is done through two phases, induction or sensitization phase is by rubbing PVA - HA composite with catgut reinforced ointment puder on the ears that lasts up to 10 days. After being rested for 3 days, followed by a second phase contact (elicitation) on day 14 and observed in the period of 24,48 , and 72 hours. Observations were made macroscopically and ear thickness was measured with a micrometer. Local toxicity testing is done by implantation of PVA HA composite with catgut reinforced on the back catgut wistar rats. Furthermore, in a certain time period, the implant material is opened and examined and observed histologically under a light microscope. The results showed no discoloration or induration on animal ears in all treatment and control groups on the sensitization and the elicitation phase. One way ANOVA statistical test showed that there were no significant differences in the results of measurements of the thickness of the wistar rats ears from all treatment groups before and after treatment on measures 24,48 and 72 hours $(\rho>0.05)$. Microscopic examination showed no infiltration of acute inflammatory cells such as neutrophils, basophils or eusinofil and chronic inflammatory cell infiltration such as macrophages, lymphocytes and plasma cells. It can be concluded that the PVA-HA composite with catgut reinforced is a material that does not cause toxicity and hypersensitivity in experimental animals, thus potentially be used as bone fractures fixation material.

Keywords: Biocompatibility, Bone Fractures, Polyvinyl Alcohol, Hydroxyapatite.

\section{ABSTRAK}

Penyambung patah tulang selama ini menggunakan alat yang kaku dan rigid dari bahan logam seperti titanium, titanium-alloy atau cobalt chrome. Di samping memiliki beberapa kelebihan, titanium sebagai alat fiksasi juga memiliki kekurangan seperti kekuatan dan kekakuan yang terlalu tinggi, menstimulus tulang terus menerus sehingga terjadi atropi tulang di bawah plat, selanjutnya menganggu pertumbuhan tulang terutama pada anak-anak. Kekurangan lain dari bahan logam ini adalah sensitif terhadap perubahan suhu dan terjadinya penyebaran ion logam pada beberapa organ. Beberapa kekurangan ini menyebabkan perlunya operasi sekunder untuk pengambilan alat ini kembali. Bahan penyambung patah tulang yang dapat diserap tubuh seperti poly-l-lactic acid (PLLA), tetapi, memiliki beberapa kekuranganjuga yang disebabkan tingginya produk berupa kristal selama proses degradasi. Monomer asam laktat yang lepas selama degradasi menimbulkan respon seluler pada tempat implan, yang memudahkan pelepasan mediator kimia seperti prostaglandine oleh fibroblas dan makrofag sebagai penyebab resorbsi tulang. Untuk itu, dalam penelitian ini ingin dikembangkan penggunaan bahan polimer lain yang memiliki biokompatibilitas yang baik dan mempunyai kekuatan mekanis yang sesuai sebagai alat fiksasi fraktur tulang yang bisa diserap tubuh, seperti Polivinil Alkohol (PVA). Penelitian sebelumnya menunjukkan bahwa komposit PVAHA dengan penguat catgut memiliki kekuatan mekanis yang cukup dan stabil sebagai bahan penyambung patah tulang. Tujuan penelitian ini adalah ingin mengetahui apakah komposit PVA-HA dengan penguat catgut memiliki biokompabilitas yang baik tanpa menimbulkan efek toksisitas dan hipersensitivitas pada hewan coba. Pengujian biokompatibilitas mencakup uji sitotoksisitas setempat dan uji hipersensitivitas kontak tipe IV. Jenis penelitian adalah eksperimental laboratorium in vivo menggunakan tikus putih galur wistar (Rattus norvegicus). Pengujian dilakukan melalui dua tahap, tahap induksi atau sensitisasi yaitu dengan pengolesan salep puder komposit PVA-HA dengan penguat catgut pada daun telinga yang berlangsung sampai dengan 10 hari. Setelah diistirahatkan selama 3 hari, dilanjutkan kontak tahap kedua (elisitasi) pada hari ke 14 dan diamati pada periode 24, 48, dan 72 jam. Pengamatan dilakukan secara makroskopis dan ketebalan telinga diukur dengan mikrometer. Uji toksisitas setempat dilakukan dengan cara penanaman (implantasi) potongan komposit PVA-HA dengan penguat catgut pada kulit punggung tikus putih galur wistar. Selanjutnya dalam periode waktu tertentu, bahan implan dibuka dan dilakukan pemeriksaan kulit punggung tikus secara histologis dan diamati di bawah mikroskop cahaya. Hasil pengamatan menunjukkan tidak adanya perubahan warna ataupun benjolan pada telinga hewan coba pada semua kelompok perlakuan dan kontrol pada tahapan sensitisasi maupun tahapan elisitasi. Uji statistik anova satu jalan menunjukkan bahwa tidak terdapat perbedaan bermakna pada hasil pengukuran ketebalan telinga tikus putih dari semua kelompok perlakuan antara sebelum dan 


\section{TAHA MA'RUF, WIDOWATI SISWOMIHARDJO, MARSETYAWAN HNE SOESATYO, ALVA EDY TONTOWI *UI BIOKOMPATIBILITAS KOMPOSIT POLIVINIL ALKOHOL-HIDROKSIAPATIT ...}

sesudah perlakuan pada pengukuran 24, 48 dan 72 jam $(\rho>0,05)$. Pemeriksaan mikroskopis tidak menunjukkan adanya infiltrasi sel radang akut seperti neutrofil, eusinofil dan basofil ataupun infiltrasi sel radang kronis seperti makrofag, limposit dan sel plasma. Dari hasil penelitian dapat disimpulkan bahwa komposit PVA-HA dengan penguat catgut merupakan bahan yang tidak menimbulkan efek toksisitas dan hipersensitivitas pada hewan coba, sehingga berpotensi digunakan sebagai bahan penyambung patah tulang.

Kata Kunci: Biokompatibilitas, Patah Tulang, Polivinil Alkohol, Hidroksiapatit.

\section{PENGANTAR}

Penyambung patah tulang selama ini menggunakan alat yang kaku dan rigid dari bahan logam seperti titanium, titaniumalloy atau cobalt chrome. Di samping memiliki beberapa kelebihan, titanium sebagai alat fiksasi juga memiliki kekurangan seperti kekuatan dan kekakuan yang terlalu tinggi, menstimulus tulang terus menerus sehingga terjadi atropi tulang di bawah plat, selanjutnya menganggu pertumbuhan tulang terutama pada anakanak (Brodke dkk., 2001; Kennady dkk., 1989). Kekurangan lainnya adalah bahan ini dapat terlihat atau teraba secara visual, sekrup mudah longgar atau terlepas, dan sensitif terhadap suhu (Goodship \& Jacobs, 2005; Bessho dkk., 1995) serta merupakan penghalang pada terapi radiasi (Mazzonetto \& Spagnoli, 2004; Scher dkk., 1998). Penelitian selanjutnya menunjukkan bahwa bahan ini menyebabkan penyebaran ionion logam pada kelenjar limfe regional (lymph nodes) dan sering menimbulkan reaksi alergi (Jorgenson dkk., 1997; Schliephake dkk., 1993). Beberapa kekurangan tersebut menyebabkan perlunya dilakukan operasi sekunder untuk pengambilan kembali alat fiksasi ini, sehingga berkembang penggunaan bahan polimer yang dapat diserap tubuh (Yerit dkk., 2002, Mazzonetto \& Spagnoli, 2004).

Bahan penyambung patah tulang yang dapat diserap tubuh seperti poly-llactic acid (PLLA) di samping menunjukkan beberapa kelebihan, juga memiliki beberapa kekurangan yang disebabkan tingginya produk berupa kristal selama proses degradasi (Kallela dkk., 1998). Monomer asam laktat yang lepas selama degradasi menimbulkan respon seluler pada tempat implan yang memudahkan pelepasan mediator kimia seperti prostaglandine oleh fibroblas dan makrofag sebagai penyebab resorbsi tulang (Wahl \& Czernuszka, 2006; Dawes \& Rushton, 1994). Untuk itu, dalam penelitian ini ingin dikembangkan penggunaan bahan polimer lain yang memiliki biokompatibilitas yang baik dan mempunyai kekuatan mekanis sesuai sebagai alat fiksasi fraktur tulang yang dapat diserap tubuh, seperti Polivinil Alkohol (PVA).

Polivinil Alkohol (PVA) selama ini banyak digunakan untuk menggantikan jaringan tubuh yang mengalami kerusakan atau penyakit karena memiliki sifat fisikokemikal terutama sifat bio-tribological yang sangat baik yaitu memiliki permukaan licin, tahan terhadap gesekan, dan keausan (Suciu dkk., 2004; Stammen dkk., 2001). Bahan ini memiliki biokompatibilitas yang sangat baik sehingga telah digunakan pada beberapa aplikasi biomedis seperti drug delivery, lensa kontak, graf tulang, penutup luka, dan jaringan lunak sendi lutut (Pan dkk., 2007; Kobayashi dkk., 2005; Peppas \& Merrill, 1997). PVA memiliki karakteristik mekanis yang rendah dan selama ini diaplikasikan pada tempat yang tidak membutuhkan kekuatan mekanis yang tinggi. Bahan penyambung patah tulang membutuhkan kekuatan mekanis yang tinggi, sehingga pada penelitian ini PVA dikompositkan dengan hidroksiapatit (HA) untuk meningkatkan kekuatan mekanisnya. Hidroksiapatit merupakan bahan bioaktif, osteokonduktif serta memiliki biokompatibilitas yang baik (Suchanek \& Yoshimura, 1998). Untuk meningkatkan kekakuan, komposit PVA-HA juga diperkuat dengan menambah anyaman menggunakan bahan bioresorbable suture yaitu catgut. Bahan ini berasal dari kolagen usus (intestine) domba dan telah digunakan 
secara luas dibidang medis termasuk ortopedi untuk penutupan jaringan yang dalam, sehingga tidak perlu diambil kembali (Kruger, 1984).

Penelitian yang dilakukan Ma'ruf dkk., (2013) menunjukkan bahwa komposit PVAHA dengan penguat catgut memiliki kekuatan mekanis yang cukup dan stabil sebagai bahan penyambung patah tulang. Selanjutnya ingin diketahui apakah komposit PVA-HA dengan penguat catgut memiliki biokompabilitas yang baik tanpa menimbulkan efek toksisitas dan hipersensitivitas pada hewan coba, sehingga dapat digunakan sebagai bahan penyambung patah tulang.

Biokompatibilitas dapat dianggap sebagai kemampuan suatu material untuk berinteraksi dengan sel-sel atau jaringan hidup atau sistem metabolisme yang tidak menyebabkan toksisitas, injuri atau reaksi imun saat berfungsi pada tempat tertentu (Bumgardner dkk., 2008). Biokompatibilitas menentukan apakah bahan tersebut dapat digunakan di dalam tubuh, di samping sifat secara fisik dan kimia, kemudahan proses, estetika, dan harga yang terjangkau. Secara umum, biokompatibilitas dapat diukur berdasarkan sitotoksisitas setempat, sistemik, dan kemampuan menimbulkan alergi serta karsinogenik (Anusavice, 2003). Tujuan dari uji biokompatibilitas adalah untuk mengetahui interaksi antara material terhadap jaringan tubuh (Williams, 1990). Respon inflamasi ditunjukkan dengan meningkatnya jumlah sel neutrofil terutama di bagian tepi dari jaringan yang mengalami reaksi toksisitas (Robbins dan Angell, 1976). Reaksi atau respon imun akan terjadi apabila terdapat penolakan terhadap bahan implan berupa reaksi hipersensitivitas (Roitt dkk., 1998).

Pengujian toksisitas terhadap material tidak hanya dilakukan pada tingkat sel (in vitro), tetapi juga dilakukan pada tingkat sistemik (in vivo). Suatu bahan dapat menimbulkan efek toksis jika bahan tersebut berhubungan langsung dengan sel atau jaringan sasaran (Shyane dan Christopher,
1998). Bahan toksik harus menembus membran yang melindungi makhluk hidup (organisme) dari pengaruh luar untuk dapat menimbulkan suatu efek toksik. Pada organisme bersel tunggal, membran tersebut terdiri dari dinding sel saja, tetapi pada organisme bersel banyak, membran tersebut terdiri atas banyak sel. Perpindahan zat toksik dari satu bagian tubuh dengan cara menembus atau beberapa membran biologik yang terjadi pada proses absorbsi, distribusi, dan ekskresi (Ngatidjan, 2006).

Reaksi toksisitas akut, diawali dengan adanya respon inflamasi pada jaringan dan secara morfologi menunjukkan gambaran sel yang membengkak, terjadi denaturasi protein dan hidrolisis, serta hilangnya komponen sel (Nicholson, 2002). Inflamasi adalah respon tubuh terhadap trauma dan invasi agen infeksi, antigen lain atau kerusakan jaringan (Navia, 1997; Gifford, 2005). Inflamasi berupa respon protektif tubuh terhadap trauma atau benda asing yang berbahaya dengan gejala lima tanda radang yang ditetapkan oleh Cornelius Celsus antara lain: sakit (dolor), panas (calor), merah (rubor), bengkak (tumor), dan hilangnya fungsi (functiolaesa) (Sudiono dkk., 2003; Baratawidjaya dan Rengganis, 2010). Tanda-tanda tersebut di atas dijumpai pada kondisi radang akut, tetapi pada radang kronis bila fokus-fokus radang sudah mulai berkurang, tanda-tanda tersebut akan menghilang (Abrams, 1995; Mitchell dan Cotran, 2003).

Setelah dilakukan pengujian terhadap efek sitotoksik bahan implan, kemudian dilakukan pengujian terhadap reaksi imun bahan implan. Reaksi atau respon imun akan terjadi apabila terdapat penolakan terhadap bahan implan, dan reaksi yang mungkin terjadi berupa reaksi hipersensitivitas. Menurut Roitt dkk. (1998), reaksi hipersensitivitas dapat diklasifikasikan ke dalam 5 tipe, yaitu hipersensitivasi I, II, III, IV, dan V. Pada penelitian ini akan dilakukan pengujian hipersensitivitas kontak tipe IV (delayed type hypersensitivity). Reaksi tipe ini 


\section{TAHA MA'RUF, WIDOWATI SISWOMIHARDJO, MARSETYAWAN HNE SOESATYO, ALVA EDY TONTOWI \& UI BIOKOMPATIBILITAS KOMPOSIT POLIVINIL ALKOHOL-HIDROKSIAPATIT ...}

tidak diperantarai oleh antibodi, tetapi oleh sel T yang bersifat antigen spesifik. Populasi sel $\mathrm{T}$ tertentu dalam organ limpoid akan teraktivasi sehingga mengeluarkan $A g-$ binding factor. Faktor yang dihasilkan oleh sel $\mathrm{T}$ tersebut akan mengaktivasi sel mast untuk menghasilkan serotonin yang mengakibatnya naiknya permeabilitas pembuluh darah, sehingga sel $\mathrm{T}$ spesifik antigen keluar dari vasa menuju jaringan. Apabila terjadi kontak ulang dengan antigen, sel T efektor (spesifik antigen) akan menghasilkan limfokin yang bersifat kemotaktik, mengakibatkan terjadinya infiltrasi sel-sel inflamasi sehingga pada tempat terjadinya reaksi, terlihat erythema dan indurasi (Bellanti, 1993; Holgate dkk., 1993; Roitt, 1998).

Proses hipersensitivitas kontak dapat dibagi menjadi 2 (dua) fase yaitu fase induksi/sensitisasi yang memiliki empat tahap, yaitu tahap persiapan, tahap pengenalan antigen, tahap aktivasi dan proliferasi, dan tahap propogasi. Fase induksi adalah fase pertamakali alergen kontak dengan komponen kulit. Fase selanjutnya adalah fase elisitasi, terjadi bila individu yang sudah tersensitisasi mendapat kontak ulang dengan alergen yang sama (Bellanti, 1993).

Penyembuhan patah tulang dibagi dalam tiga tahap yang saling overlapping, yaitu (1) Perdarahan, diikuti dengan pembentukan bekuan darah (clot) dan proliferasi pembuluh darah, terjadi selama 10 hari; (2)Pembentukan kalus, diawali terbentuknya kalus primer yaitu suatu anyaman tulang yang kasar (1020 hari), dilanjutkan terbentuknya kalus sekunder yang merupakan sistem haversian (20-60 hari); (3) Perbaikan fungsional, tulang yang berlebihan hilang dan bentuk tulang kembali normal sesuai fungsinya (2-3 tahun).

Radang merupakan proses yang komplek, yang menyebabkan terjadinya perubahan di dalam jaringan tubuh. Mekanisme radang dikelompokkan dalam tiga kejadian yang saling berhubungan, yaitu perubahan pada pembuluh darah (perubahan hemodinamik), eksudasi cairan (perubahan permeabilitas) dan eksudasi seluler (keluarnya sel-sel leukosit). Setiap terjadi cidera, terjadi rangsangan untuk dilepaskannya zat kimia tertentu yang akan menstimulasi terjadinya perubahan jaringan tempat jejas tersebut. Mediator kimia radang ini adalah histamin, serotonin, globulin tertentu, dan nukleotida. Zat-zat kimia ini akan tersebar di dalam jaringan dan menyebabkan perubahan pada sel endotel pembuluh darah sehingga permeabilitas dinding pembuluh darah meningkat. Cairan plasma keluar ke jaringan sehingga menyebabkan tekanan hidrostatik darah lebih tinggi. Dengan keluarnya cairan dari pembuluh darah, sel-sel darah merah akan berubah menjadi lebih lengket satu sama lain dan menggumpal yang mengakibatkan aliran darah menjadi lambat (stasis), bahkan kadang-kadang terhenti sama sekali (Sudiono dkk., 2003; Price dan Wilson, 2005).

Pada keadaan normal, permeabilitas dinding kapiler terbatas sehingga hanya dapat dilalui oleh zat-zat tertentu seperti air, garam, asam amino, glukosa, dan molekul lain yang kecil. Adanya tekanan yang seimbang antara tekanan hidrostatik (darah) dan tekanan osmotik koloid (protein plasma) di dalam pembuluh darah akan mengatur keluar masuknya bermacam-macam cairan melalui membran endotelnya. Pada proses radang, protein besar akan lepas ke luar dari aliran darah. Kondisi ini menyebabkan tekanan koloid osmotik dalam pembuluh darah menurun sehingga tekanan hidrostatiknya menjadi bertambah tinggi. Menurunnya tekanan koloid osmotik menyebabkan permeabilitas kapiler bertambah besar sehingga cairan eksudat akan keluar dari pembuluh darah dan berkumpul di dalam jaringan sekitar pembuluh darah, menimbulkan udema (Sudiono dkk., 2003; Price dan Wilson, 2005).

Protein yang terlepas ini sebagian akan hancur dan mengakibatkan tekanan osmotik jaringan bertambah besar sehingga cairan 
plasma tidak dapat mengalir masuk ke dalam pembuluh darah. Akibatnya tekanan osmotik dalam darah semakin turun, sedangkan tekanan hidrostatiknya semakin tinggi selama berlangsungnya kongesti radang. Jika cidera cukup berat, bahan molekul protein besar seperti fibrinogen akan ikut keluar dan masuk ke jaringan dan dapat membentuk suatu massa karena ada penggumpalan. Eksudasi cairan ini biasanya segera terjadi setelah ada proses radang dan berlanjut terus menjadi lebih nyata setelah 24 jam berikutnya.

Adanya penggumpalan fibrinogen ini dapat menyumbat saluran limfe dan selasela jaringan sehingga dapat menghambat penyebaran infeksi atau radang. Radang yang terjadi pada permukaan tubuh menyebabkan terbentuknya lapisan bekuan fibrin yang akan mencegah penyebaran. Setelah radang mereda, fibrin akan mencair lagi dan akan diabsorbsi. Jika absorbsi fibrin terhambat, akan dimasuki sel fibroblas dan kemudian berubah menjadi jaringan ikat sehingga menyebabkan perlekatan (Sudiono dkk., 2003; Price dan Wilson, 2005).

Perubahan pada endotel kapiler akan menyebabkan keluarnya sel darah ke daerah cidera, sebagian besar merupakan sel polimorfonuklear (PMN) terutama neutrofil. Setelah menempel pada dinding kapiler, leukosit akan mengeluarkan pseudopodia, kemudian akan bergerak secara amuboid menembus dinding kapiler keluar ke jaringan, proses ini disebut emigrasi. Neutrofil adalah sel pertama yang menuju daerah radang, jumlahnya meningkat cepat dan mencapai puncak pada 24-48 jam. Neutrofil memiliki metabolisme yang sangat aktif dan mampu melakukan glikosis baik secara aerob maupun anaerob, memiliki kemampuan untuk membunuh bakteri serta membersihkan debris pada jaringan nekrotik (Effendy, 2003).

Migrasi sel darah putih yang terarah ini disebabkan oleh pengaruh kimia yang dapat berdifusi disebut kemotaksis. Hampir semua jenis sel darah putih dipengaruhi oleh faktor-faktor kemotaksis dalam derajat yang berbeda-beda. Neutrofil dan monosit paling reaktif terhadap rangsang kemotaksis, sebaliknya limfosit bereaksi lemah. Faktorfaktor kemotaksis dapat endogen berasal dari protein plasma atau eksogen misalnya produk bakteri (Robbins dan Kumar, 1995).

Bersama dengan invasi neutrofil, maka monosit akan mulai memasuki jaringan yang meradang (Guyton dan Hall, 1997). Monosit muncul pertama 48-96 jam setelah terjadi radang, bergerak lebih lambat karena itu sel ini pada radang akut tidak terlihat banyak sampai hari pertama atau kedua setelah radang. Elemen seluler berikutnya adalah makrofag yang merupakan turunan dari monosit yang bersirkulasi, terbentuk karena proses kemotaksis dan migrasi. Beberapa menit setelah terjadi peradangan, makrofag telah terdapat dalam jaringan dan segera melakukan aktivitas fagositiknya. Apabila makrofag diaktifkan oleh produk infeksi dan peradangan, efek yang mula-mula terjadi adalah pembesaran setiap sel-sel makrofag dengan cepat (Lawyer dkk., 1992; Robbins dan Angell, 1976).

Makrofag memfagositosis dan mencerna organisma patologis dan sisa-sisa jaringan. Makrofag juga melepas zat biologis aktif, yang mempermudah terbentuknya sel inflamasi tambahan yang membantu dalam dekontaminasi dan membersihkan sisa jaringan. Makrofag melepas faktor pertumbuhan dan substansi lain yang mengawali dan mempercepat pembentukan jaringan granulasi (Sudrajat, 2005). Meskipun sel-sel fagosit dapat melekat pada partikel dan bakteri tanpa didahului oleh suatu proses pengenalan yang khas, tetapi fagositosis akan sangat ditunjang apabila mikroorganisme diliputi oleh opsonin, yang terdapat dalam serum (misalnya IgG, C3).

Setelah bakteri yang mengalami opsonisasi melekat pada permukaan, selanjutnya sel fagosit sebagian besar akan meliputi partikel, berdampak pada pembentukan kantung yang dalam. Partikel ini terletak pada vesikel sitoplasma yang masih terikat pada selaput 


\section{TAHA MA'RUF, WIDOWATI SISWOMIHARDJO, MARSETYAWAN HNE SOESATYO, ALVA EDY TONTOWI \& UI BIOKOMPATIBILITAS KOMPOSIT POLIVINIL ALKOHOL-HIDROKSIAPATIT ...}

sel, disebut fagosom. Meskipun pada waktu pembentukan fagosom, sebelum menutup lengkap, granula-granula sitoplasma neutrofil menyatu dengan fagosom dan melepaskan isinya ke dalamnya, suatu proses yang disebut degranulasi (Robbins dan Kumar, 1995).

\section{Bahan dan Metode Pembuatan Komposit PVA-HA dengan Penguat Catgut}

Pembuatan spesimen mengacu seperti yang dilakukan oleh Ma'ruf, dkk. (2013). Serbuk PVA dan HA bovine ditimbang masing-masing sesuai dengan perbandingan kelompoknya; PVA dilarutkan dalam akuades dengan perbandingan $w / v 7,5 \%$, dipanaskan pada suhu $95^{\circ} \mathrm{C}$ dengan 600 putaran permenit (rpm) selama 30 menit; Setelah PVA larut, ditambahkan HA bovine sesuai perbandingan kelompoknya, diaduk dengan mesin stirer dan dipanaskan pada suhu $60{ }^{\circ} \mathrm{C}$ dengan putaran 600 rpm selama 60 menit; Proses lay up dilakukan selapis demi lapis pada cetakan yang sudah diberi lapisan anyaman benang catgut, dipanaskan menggunakan oven pada suhu $70{ }^{\circ} \mathrm{C}$ selama 15 menit; Dilakukan proses lay up dan pemanasan selanjutnya sampai jumlah layer dan ketebalan yang diinginkan; Setelah cetakan penuh, dipanaskan menggunakan oven pada suhu $70{ }^{\circ} \mathrm{C}$ selama 2 jam; Setelah dingin, spesimen dikeluarkan dari cetakan dan dipanaskan menggunakan oven pada suhu $70^{\circ} \mathrm{C}$ selama 2 jam.

\section{A. Uji Hipersensitivitas Kontak Tipe IV (Patch Tes)}

Jenis penelitian adalah eksperimental laboratorium in vivo. Subjek penelitian adalah 20 ekor tikus putih galur wistar (Rattus norvegicus), dengan kriteria jenis kelamin betina, umur 3 bulan dan berat 200250 gram. Rancangan penelitian terdiri dari 3 (tiga) kelompok perlakuan dan 1 (satu) kelompok kontrol, masing-masing terdiri dari 5 (lima) ekor. Kelompok perlakuan dibedakan berdasarkan konsentrasi komposit PVA-HA dengan penguat catgut terhadap salep vaselin yaitu 2,5\%, 5\% dan 10\%. Kelompok kontrol adalah mengandung salep vaselin saja. Sampel penelitian adalah kulit punggung dan telinga tikus Wistar. Pemaparan dilakukan 2 (dua) tahap yaitu tahap sensitisasi dan elisitasi.

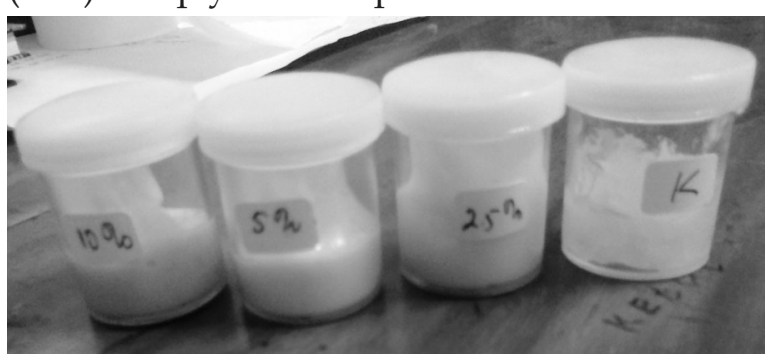

Gambar 1 Salep puder komposit PVA-HA dengan penguat catgut

Gambar 1 menunjukkan salep puder komposit PVA-HA dengan penguat catgut. Spesimen komposit PVA-HA dengan penguat catgut dipotong dan digerus menggunakan wadah keramik (mortal) sampai halus. Serbuk yang sudah halus ditimbang menggunakan timbangan digital dan dicampur dengan vaselin menggunakan mortal sesuai konsentrasi masing-masing. Setelah didapatkan konsentrasi serbuk dalam vaselin $2,5 \% ; 5 \%$ dan $10 \%$, salep dimasukkan dalam botol plastik tertutup dan diberi tanda.

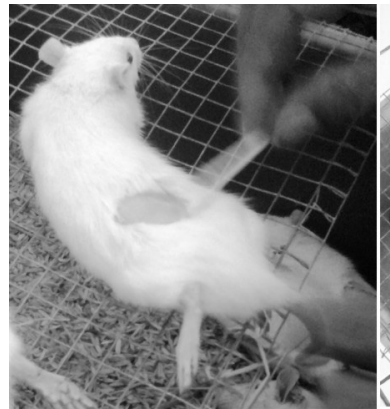

(a)

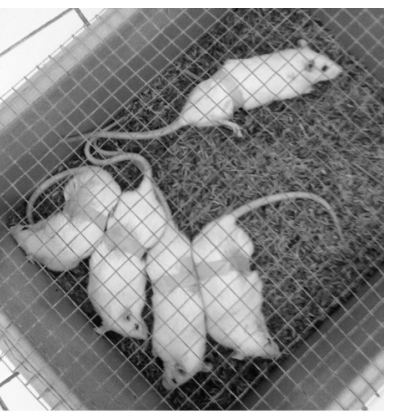

(b)
Gambar 2 Uji hipersensitivitas kontak tipe IV; (a) Pencukuran dan pengolesan salep; (b) Kulit punggung diplaster melingkari tubuh

Pengujian dilakukan melalui dua tahap, tahap induksi atau sensitisasi berlangsung sampai dengan 10 hari. Setelah diistirahatkan selama 3 hari, dilanjutkan kontak tahap kedua (elisitasi) pada hari ke 14 dan diamati 
pada periode 24,48 , dan 72 jam. Tikus putih galur wistar (Rattus norvegicus) 20 ekor dibagi menjadi 4 kelompok, masing-masing terdiri dari 5 ekor. Semua hewan coba dibius dengan ketamin 0,2 cc dan dicukur pada kulit punggungnya (Gambar 2.a). Kelompok I (kontrol) diolesi bahan dasar salep (vaselin) pada kulit punggung, kemudian dibalut dengan plester dengan lebar $2,5 \mathrm{~cm}$. Kelompok II, III, IV, diolesi salep puder komposit PVA-HA dengan penguat catgut dengan konsentrasi berturut-turut 2,5\%,5\% dan $10 \%$, kemudian dibalut dengan plester selebar 2,5 cm (Gambar 2.b); Plester dibuka setelah 10 hari. Setelah diistirahatkan selama 3 hari, kemudian pada hari ke 14 dilakukan kontak tahap kedua (elisitasi) yaitu dengan pengolesan salep puder komposit PVA-HA dengan penguat catgut sesuai kelompoknya pada daun telinga. Sebelum diolesi salep, dilakukan pengamatan secara makroskopis dan ketebalan telinga diukur dengan mikrometer.

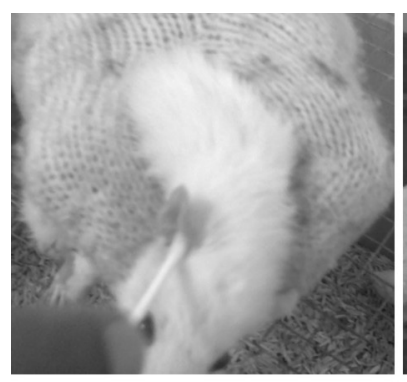

(a)

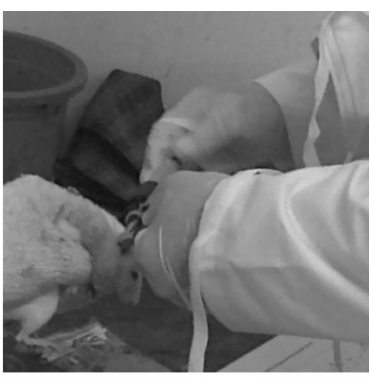

(b)
Lambar 3 lahap elısitasi; (a) rengolesan salep pada telinga luar; (b) Mikrometer; (c) Pengukuran telinga dengan mikrometer

Pada periode waktu 24, 48, dan 72 jam dilakukan pengamatan makroskopis pada telinga hewan coba (Gambar 3.a) dan dilakukan pengukuran ketebalan telinga menggunakan mikrometer (Gambar 3.b). Hasil pengamatan makroskopis dicatat dengan cara pemberian skor 0-2 (Holgate dan Church, 1993), yaitu 0 (tidak ada tanda merah); 0,5 (warna pink/merah muda); 1 (warna merah merata); 2 (benjolan warna merah); selanjutnya dilakukan analisis data menggunakan uji statistik ANOVA satu jalan.

\section{B. Uji Toksisitas Setempat}

Uji toksisitas setempat dilakukan dengan cara penanaman (implantasi) potongan komposit PVA-HA dengan penguat catgut pada kulit punggung tikus putih galur wistar. Selanjutnya dalam periode waktu tertentu, bahan implan dibuka dan dilakukan pemeriksaan kulit punggung tikus secara histologis dan diamati di bawah mikroskop cahaya.

\section{Tahapan Implantasi pada Hewan Coba}

Jenis penelitian adalah eksperimental laboratorium in vivo. Subjek penelitian adalah 8 (delapan) ekor tikus putih galur wistar (Rattus norvegicus). Sampel penelitian adalah kulit punggung tikus Wistar. Rancangan penelitian adalah terdiri dari 1 (satu) kelompok perlakuan berjumlah 5 ekor dan 1 (satu) kelompok kontrol, berjumlah 3 (tiga) ekor. Kelompok perlakuan adalah kelompok yang diimplankan potongan komposit PVAHA dengan penguat catgut berukuran $0,5 \times 0,5$ $x 0,5 \mathrm{~cm}$ di bawah kulit (subkutan) punggung tikus wistar. Kelompok kontrol adalah kelompok tikus tanpa dipasang implan.

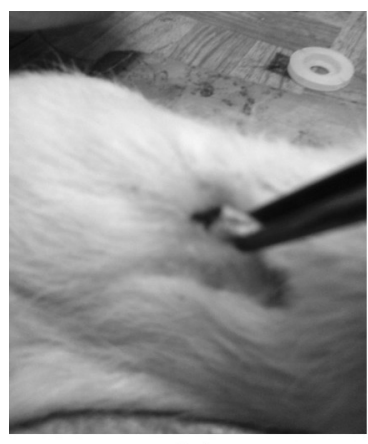

(a)

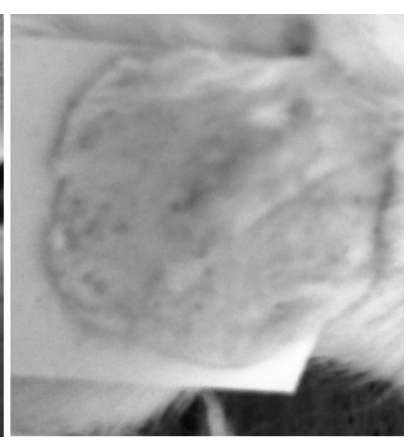

(b) kulit punggung dan penanaman implan; (b) Eksisi kulit punggung setelah 5 hari

Lima hewan coba dibius dengan ketamin $100 \mathrm{mg}$ sebanyak 0,2 ml. Kulit punggung hewan coba dicukur berukuran 
$2 \times 2 \mathrm{~cm}$ dan diinsisi pada bagian kulitnya. Potongan komposit PVA-HA dengan penguat catgut berukuran $0,5 \times 0,5 \times 0,5 \mathrm{~cm}$ dimplankan di bawah kulit (subkutan) punggung hewan coba dan dilakukan penjahitan luka (Gambar 4.a). Setelah 5 hari, hewan coba didekapitasi. Kulit punggung hewan coba dipotong (eksisi) berukuran $2,5 \times 2,5 \mathrm{~cm}$ dan di simpan dalam wadah berisi cairan fiksatif (PBS 10\% dan formalin) (Gambar 4.b). Selanjutnya dilakukan prosedur pemeriksaan histologis yang meliputi pembuatan blok parafin, pengirisan dengan mikrotom dan pewarnaan dengan hemaktosilin eosin (HE).

\section{Pembuatan Sediaan dan Pemeriksaan Histologis Pembuatan Blok Parafin}

Jaringan disiapkan dalam botol yang berisi cairan fiksatif PBS - formalin 10\% dengan ketebalan $0,5 \times 1 \times 1 \mathrm{~cm}$. Dilakukan proses dehidrasi, clearing dan embedding, Selanjutnya dilakukan proses infiltrasi di dalam inkubator suhu $60{ }^{\circ} \mathrm{C}$ dengan cara mencairkan parafin di dalam inkubator $60{ }^{\circ} \mathrm{C}$. Parafin cair dituang ke dalam cetakan atau kaset, jaringan diletakkan di dalamnya. Cetakan diletakkan di suhu ruang hingga beku, blok disimpan pada suhu $4{ }^{\circ} \mathrm{C}$.

\section{Pemotongan dengan Mikrotom}

Gambaran histologis dapat diamati di bawah mikroskop pada jaringan dengan ketebalan tertentu $(\mu m)$. Untuk memperoleh ketebalan yang diinginkan, diperlukan suatu teknik pemotongan jaringan yang baik agar dapat dihasilkan potongan yang sempurna dan dapat dilihat di bawah mikroskop.

Setelah didapatkan irisan jaringan, diambil menggunakan kuas dan diletakkan pada wadah yang berisi akuades. Kemudian irisan jaringan dipindahkan menggunakan kuas ke dalam waterbath. Gelas obyek disiapkan dan telah diberi label yang unik. Irisan jaringan ditempelkan di atas gelas obyek yang telah diberi perekat dengan cara membenamkan gelas obyek di bawah irisan jaringan kemudian diangkat dengan hati-hati. Sediaan dikeringkan pada hot plate suhu $40{ }^{\circ} \mathrm{C}$ selama 3 jam. Irisan jaringan siap digunakan untuk proses selanjutnya.

\section{Pewarnaan}

Pewarnaan bertujuan memberi warna pada jaringan yang akan diamati di bawah mikroskop cahaya. Hemaktosilin akan mengecat inti sel berwarna biru, sedangkan eosin akan mengecat sitoplasma dan matriks ekstra selular berwarna merah. Hasil diamati di bawah mikroskop.

\section{Pengamatan}

Pengamatan slide dilakukan dengan menggunakan mikroskop cahaya Olymphus ${ }^{\circledR}$ dengan pembesaran 40 kali. Hasil pengamatan diproses dan ditampilkan menggunakan optilab® viewer 2.1.

\section{PEMBAHASAN}

\section{Uji Hipersensitivitas Kontak Tipe IV (Patch Test)}

Pengujian dengan metode patch test dilakukan dalam dua tahap, yaitu tahap sensitisasi dan elisitasi. Tahap sensitisasi dilakukan dengan cara kontak tahap pertama yang berlangsung sampai dengan 10 hari, dilanjutkan dengan kontak tahap kedua (tahap elisitasi) pada hari ke 14 setelah diistirahatkan selama 3 hari. Pengamatan dilakukan pada 24, 48, dan 72 jam setelah kontak tahap kedua tersebut, dengan melihat adanya perubahan bentuk dan warna daun telinga hewan coba secara makroskopis serta adanya penebalan telinga. Tabel 1 menampilkan tabulasi pengamatan secara makroskopis perubahan bentuk dan warna telinga tikus putih pada tahap sensitisasi dan elisitasi. 
Tabel 1

Pengamatan makroskopis telinga tikus putih tahap sensitisasi dan elisitasi

\begin{tabular}{llllll}
\hline \multirow{2}{*}{ Klp } & $\mathrm{n}$ & $\begin{array}{l}\text { Hari ke 10 } \\
\text { Rerata }\end{array}$ & $\begin{array}{l}\text { 24 jam } \\
\text { Rerata }\end{array}$ & $\begin{array}{l}48 \text { jam } \\
\text { Rerata }\end{array}$ & $\begin{array}{l}72 \text { jam } \\
\text { Rerata }\end{array}$ \\
\hline $2,5 \%$ & 5 & 0 & 0 & 0 & 0 \\
$5 \%$ & 5 & 0 & 0 & 0 & 0 \\
$10 \%$ & 5 & 0 & 0 & 0 & 0 \\
$\mathrm{~K}$ & 5 & 0 & 0 & 0 & 0 \\
\hline
\end{tabular}

Setelah dilakukan pengamatan secara makroskopis, dilakukan pengukuran ketebalan telinga tikus putih dengan menggunakan mikrometer. Data ketebalan telinga yang dicatat pada periode 24 , 48, dan 72 jam setelah tahap elisitasi dibandingkan dengan data ketebalan telinga sebelum perlakuan dan kelompok kontrol. Tabel 2 menampilkan rerata dan simpang baku ketebalan telinga tikus putih sebelum dan sesudah perlakuan.

Tabel 2

Rerata dan simpang baku ketebalan telinga tikus putih sebelum dan sesudah perlakuan

\begin{tabular}{|c|c|c|c|c|c|c|c|c|c|}
\hline \multirow[b]{2}{*}{ Klp } & \multirow[b]{2}{*}{$\mathrm{n}$} & \multicolumn{2}{|c|}{ Pre } & \multicolumn{2}{|c|}{24 jam } & \multicolumn{2}{|c|}{48 jam } & \multicolumn{2}{|c|}{72 jam } \\
\hline & & $\begin{array}{c}\text { Rerata \& } \\
\text { SB }\end{array}$ & $p$ & $\begin{array}{c}\text { Rerata \& } \\
\text { SB }\end{array}$ & $p$ & $\begin{array}{c}\text { Rerata \& } \\
\text { SB }\end{array}$ & $p$ & $\begin{array}{c}\text { Rerata \& } \\
\text { SB }\end{array}$ & $p$ \\
\hline $2,5 \%$ & 5 & $0,40 \pm 0,05$ & & $0,43 \pm 0,05$ & & $0,45 \pm 0,04$ & & $0,45 \pm 0,01$ & \\
\hline $5 \%$ & 5 & $0,45 \pm 0,03$ & & $0,47 \pm 0,03$ & & $0,46 \pm 0,03$ & & $0,45 \pm 0,03$ & \\
\hline $10 \%$ & 5 & $0,43 \pm 0,02$ & & $0,46 \pm 0,02$ & & $0,47 \pm 0,01$ & & $0,44 \pm 0,01$ & \\
\hline $\mathrm{K}$ & 5 & $0,44 \pm 0,06$ & 0.308 & $0,48 \pm 0,05$ & 0.186 & $0,47 \pm 0,05$ & 0.744 & $0,47 \pm 0,05$ & 0.770 \\
\hline
\end{tabular}

Hasil pengamatan secara makroskopis menunjukkan tidak adanya perubahan warna ataupun benjolan pada telinga hewan coba pada semua kelompok perlakuan dan kontrol pada tahapan sensitisasi maupun tahapan elisitasi. Uji statistik anova satu jalan menunjukkan bahwa tidak terdapat perbedaan bermakna pada hasil pengukuran ketebalan telinga tikus putih dari semua kelompok perlakuan antara sebelum dan sesudah perlakuan pada pengukuran 24, 48, dan 72 jam $(\rho>0,05)$. Dari Tabel 1 dan 2 tersebut dapat disimpulkan bahwa komposit PVA-HA dengan penguat catgut tidak menyebabkan reaksi hipersensitivitas kontak tipe IV pada hewan coba.

\section{Uji Toksisitas Setempat}

Uji toksisitas setempat dilakukan dengan cara penanaman potongan komposit PVA-HA dengan penguat catgut pada kulit punggung tikus putih galur wistar. Pada hari ke-6, bahan implan dibuka dan dilakukan pemeriksaan kulit punggung tikus secara histologis dan diamati di bawah mikroskop cahaya. Pemeriksaan yang sama juga dilakukan pada kelompok kontrol yaitu kelompok tikus tanpa dipasang implan.
Gambar 5 menampilkan gambaran histologis potongan jaringan kulit punggung tikus pada kelompok perlakuan dan kontrol tersebut.

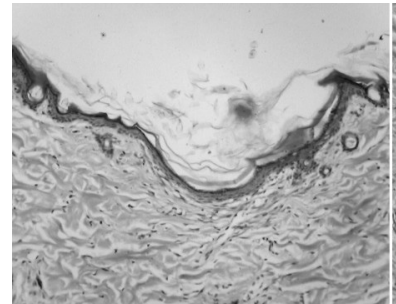

(a)

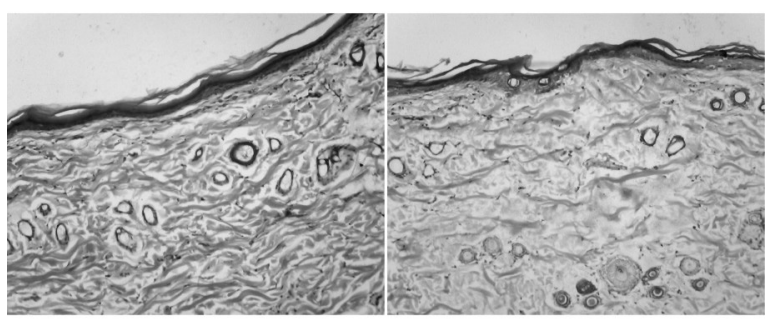

(C)

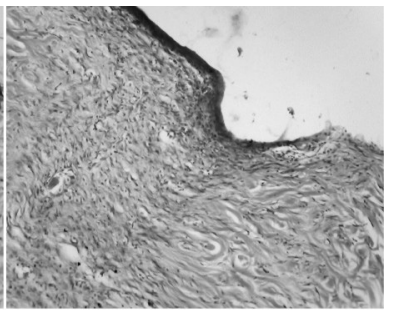

(b)
Gambar 5 Gambaran mikroskopis jaringan kulit punggung tikus setelah implantasi $(a, b)$ dan kontrol (c,d) dengan perbesaran 40 kali.

(Ket. $\mathrm{EBP}=$ epitel berlapis pipih; $\mathrm{LP}=$ lamina propria)

Gambar 5 menunjukkan tidak terdapatnya infiltrasi sel radang akut seperti neutrofil, eusinofil, dan basofil ataupun infiltrasi sel radang kronis seperti 


\section{TAHA MA'RUF, WIDOWATI SISWOMIHARDJO, MARSETYAWAN HNE SOESATYO, ALVA EDY TONTOWI UJI BIOKOMPATIBILITAS KOMPOSIT POLIVINIL ALKOHOL-HIDROKSIAPATIT ...}

makrofag, limposit dan sel plasma. Kondisi tersebut menunjukkan bahwa komposit PVA-HA dengan penguat catgut tidak menyebabkan reaksi toksisitas setempat yang ditandai dengan tidak adanya infiltrasi sel radang. Pencarian bahan yang memadai untuk digunakan dalam tubuh manusia (biomaterial) awalnya didasarkan pada konsep bioinert, yaitu bahan tersebut tidak akan menimbulkan reaksi pada jaringan sekitarnya. Konsep ini sebenarnya telah berubah karena bukti menunjukkan bahwa tidak ada material implan yang benar-benar inert pada jaringan tubuh dan tetap akan menstimulasi respon imun. Menurut Case dkk. (1994), serpihan yang disebarkan oleh beberapa material ini adalah tidak inert dan akan difagositosis oleh makrofag.

Mekanisme imun dimulai ketika material diimplankan di dalam tubuh, sel-sel sistem imun segera menumpuk di tempat implantasi dan terjadi serangkaian proses pada tempat tersebut. Semua sel dari sistem imun, makrofag dan limfosit $\mathrm{T}$ paling banyak ditemukan dan menetap dalam jaringan sekitar implan. Interaksi antara sel-sel ini menyebabkan pelepasan sekresi sitokin yaitu suatu molekul terlarut yang terlibat dalam proses inflamasi awal yang dapat menyebabkan terjadinya penolakan (rejection) (Cachinho dan Hunt, 2008).

Implantasi material menyebabkan beberapa kejadian terhadap reaksi tubuh terhadap benda asing, dimulai dari respon inflamasi akut dan pada beberapa kasus menyebabkan respon inflamasi kronis, terbentuknya jaringan granulasi, timbulnya reaksi tubuh terhadap benda asing dan pembentukan kapsul fibrus. Lamanya dan intensitas masing-masing respon ini tergantung atas luasnya injuri yang terjadi pada implantasi, komposisi kimia material, bentuk permukaan, porositas, kekasaran, bentuk, dan ukuran implan (Li dkk., 2005).

Sistem imun manusia terdiri dari organ limfoid, sel-sel spesifik dan sistem sirkulasi yang menyebabkan perlindungan tubuh dari kerusakan dan penyakit. Mekanisme pertahanan tubuh ini dibagi dalam 2 (dua) katagori yaitu didapat (acquired) atau spesifik dan bawaan (innate) atau non spesifik (Chaplin, 2003). Proses dua katagori ini sangat berbeda meskipun sama-sama dipengaruhi dan dimediasi oleh agen yang sama. Sel-sel seperti makrofag berperanan penting pada respon spesifik dan non spesifik (Pruett, 2003).

Sistem imun bawaan (innate) ada pada setiap individu, membutuhkan sedikit atau tidak sama sekali periode induksi, dan tidak merespon lebih cepat atas kontak tahap kedua (tidak menunjukkan respon memori). Sistem imun ini dimediasi oleh neutrofil, eosinofil, basofil, makrofag dan natural killer cells (sel limfosit besar). Sel-sel ini bekerja dengan cara aksi antimikroba langsung dengan membunuh sel-sel infeksi-virus atau sel tumor, dan mengeluarkkan sitokin yang menyebabkan rangkaian mekanisme inflamasi dan pertahanan tubuh lainnya (Pruett, 2003). Respon imun didapat (acquired) membutuhkan stimulasi atau imunisasi agar diaktivasi dan dimediasi oleh limfosit. Masing-masing limfosit mempunyai reseptor pada permukaannya yang dapat mengenali hanya satu konfirmasi (antigenic determinant). Setelah pengenalan dari antigen spesifik, limfosit akan berproliferasi membentuk clones (Cachinho dan Hunt, 2008).

Pada proses imun acquired, makrofag bertindak sebagai antigen-presenting cells (APC) pada tahap awal (Muno, 2000). Sel fagositik memindahkan fragmen ke permukaan sel bekerjasama dengan molekul major histocompatibility complex (MHC) dan terlibat dalam perlekatan limfosit T (King dan Wills, 2005). APC akan menstimulasi respon kedua dengan cara mempresentasikan antigen ke limposit $\mathrm{T}$ yang sudah siap diekpos ke antigen. Makrofag memainkan peran penting tidak hanya sebagai APC, tetapi juga sebagai sumber sitokin yang dapat mengatur respon limfosit T yang muncul. Proses pengenalan antigen dibagi menjadi dua jalur yang 
mengarah pada fragmen peptida dari antigen asing yang dipresentasikan oleh molekul MHC kelas I (jalur endogen) dan MHC kelas II (jalur eksogen) (Cachinho dan Hunt, 2008).

Limfosit adalah sel yang bertanggung jawab pada respon imun acquired. Limfosit $\mathrm{T}$ bertanggung jawab atas respon imun seluler dan sel B bertanggung jawab atas respon imun humoral yang dimediasi oleh antibodi (Sirica, 1996). Limfosit T berasal dari pluripotent stem cells dalam sumsum tulang, mengalami perubahan dalam timus dan menyebabkan ekspresi reseptor antigennya yaitu reseptor antigen limfosit $\mathrm{T}$ atau T-lymphocyte antigen receptor (TCR) (King dan Wills, 2005).

Luyn dkk. (2001) melakukan penelitian untuk mengetahui apakah aplikasi subkutan berulang dari jenis bahan yang sama bisa menyebabkan timbulnya reaksi tubuh terhadap benda asing. Dua biomaterial biodegradabel dan non biodegradabel diuji dalam model implantasi berulang. Peningkatan reaksi benda asing diamati dengan melihat peningkatan sel ingrowth, peningkatan vaskularisasi, adanya sel $\mathrm{MHC}$ positif kelas II dan infiltrasi sel plasma dalam jaringan sekitarnya. Hasil penelitian menunjukkan bahwa perubahan terjadi pada kedua bahan biodegradabel dan non biodegradabel. Kondisi ini menunjukkan bahwa perubahan yang terjadi tidak disebabkan oleh produk biodegradasi dari material tersebut.

\section{SIMPULAN}

Dari hasil penelitian dan pembahasan di atas dapat disimpulkan bahwa komposit PVA-HA dengan penguat catgut merupakan bahan yang biokompatibel tanpa menimbulkan efek toksisitas dan hipersensitivitas pada hewan coba, sehingga berpotensi digunakan sebagai bahan penyambung patah tulang.

\section{DAFTAR PUSTAKA}

Abrams, G.D., 1995, Respon tubuh terhadap cedera, dalam S.A. Price \& L.M. Wilson, Patofisiologi: Konsep klinis proses-proses penyakit. $4^{\text {th }}$. ed., (Anugerah, P. penerjemah), Jakarta: EGC (Buku asli diterbitkan 1992), hal. 35-61.

Anusavice, K.J., 2003, Phillips'Science of Dental Materials, $8^{\text {th }}$ ed., St. Louis, Missouri, USA: Saunders Co.

Baratawidjaya, K.G., dan Rengganis, I., 2010, Imunologi Dasar, 9 ${ }^{\text {th }}$ ed., Fakultas Kedokteran Gigi, Universitas Indonesia, Jakarta.

Bellanti, J.A., 1993, Immunology III (terjemahan), Yogyakarta: Gadjah Mada University Press., hal. 173-202.

Bessho, K., Fujimura, K., dan Iizuka T., 1995, "Experimental long-term study of titanium ions eluted from pure titanium miniplates", J Biomed Mater Res., 29, hal. 901-904.

Brodke, D.S., Gollogly, S., Alexander, Mohr. R., Nguyen, B.K., Dailey, A.T., dan Bachus, aK., 2001, “Dynamic cervical plates: biomechanical evaluation of load sharing and stiffness", Spine, 26(12), hal. 1324-1329.

Bumgardner, J.D., Vasquez-Lee, M., Fulzele, K., Smith, D., Branch, K., Christian, S.I., 2008, Biocompatibility Testing, dalam Encyclopedia of Biomaterials and Biomedical Engineering, 2 ${ }^{\text {nd }}$ ed., Diedit oleh David L. Williams, hal. 169-178.

Cachinho S.C.P., dan Hunt J.A., Biomaterials Immune Response, dalam Encyclopedia of Biomaterials and Biomedical engineering, $2^{\text {nd }}$ ed., Diedit oleh G.E. Wnek, dan G.L. BoWlin, New York: Vanderbilt Avenue, hal. 264-268.

Case, C.P., Langkamer, V.G., James, C., Palmer, M.R., Kemp, A.J., Heap, P.F., dan Solomon, L., 1994, “Widespread dissemination of metal debris from implants", Journal of Bone and Joint 


\section{TAHA MA'RUF, WIDOWATI SISWOMIHARDJO, MARSETYAWAN HNE SOESATYO, ALVA EDY TONTOWI *UI BIOKOMPATIBILITAS KOMPOSIT POLIVINIL ALKOHOL-HIDROKSIAPATIT ...}

Surgery,76B(5), hal. 701-712.

Chaplin, D.D., 2003, "Overview of the immune response", J. Allerg. Clin. Immunol., 111(2), hal. 442-459.

Dawes, E., dan Rushton, N., 1994, “The effects of lactic acid on PGE2 production by macrophages and human synovial fibroblasts: a possible explanation for problems associated with the degradation of poly(lactide) implants?", Clin Mater., 17, hal. 157163.

Effendy, Z., 2003, Peranan Leukosit Sebagai Anti Inflamasi Alergik Dalam Tubuh, Bagian Histologi Fakultas Kedokteran USU, Medan.

Gifford, L., 2005, Pathophysiology: An Essential Text For The Allied Health Profession, Oxford Philadelphia St Louis Sydney Toronto.

Goodship, V., dan Jacobs, D., 2005, Polyvinyl alcohol: Materials, procesing and applications, review reports, Rapra Review Reports, 16(12), hal. 3-24.

Guyton, A.C., dan Hall, J.E., 1997, Fisiologi Kedokteran (terjemahan), Jakarta: Penerbit EGC, hal. 549-550.

Holgate, S.T., dan Church, M.K., 1993, Allergy, New York, USA: Gower Medical Publishing, hal. 211-281.

Jorgenson, D.S., Mayer, M.H., Ellenbogen, R.G., Centeno, J.A., Johnson, F.B., dan Mullick, F.G., 1997, “Detection of titanium in human tissues after craniofacial surgery", Plast Reconstr Surg., 99, hal. 976-979.

Kallela, I., Tulamo, R.M., Hietanen, C.J., Pohjonen, T., Suuronen, R., dan Lindqvist, C., 1999, "Fixation of mandibular body osteotomies using biodegradable amorphous selfreinforced (70L:30DL) polylactide or metal lag screws: an experimental study in sheep", J Craniomaxillofac
Surg., 27, hal. 124-133.

Kennady, M.C., Tucker, M.R., Lester, G.E., dan Buckley, M.J., 1989, "Histomorfometric evaluation of stress shielding in mandibular continuity defects treated with rigid fixation plates and bone grafts", Int J Oral Maxillofac Surg., 18, hal.170-174.

King, C.A., dan Wills, M.R., 2005, "Immunology II: Acquired immunity", Surgery, 23(9), hal. 319323.

Kobayashi, M., Chang, Y.S., dan Oka, M., 2005, "A two year in vivo study of polyvinyl alcohol-hydrogel (PVA-H) artificial meniscus", Biomaterials, 26, hal. 3243-3248.

Kruger, E., 1984, Oral and Maxillofacial Traumatology, vol.1, Chicago, Quintessence: Publishing Company.

Lawyer, W.S., Ali-Ahmed., dan Hume, J.W., 1992, Buku Pintar Patologi untuk Kedokteran Gigi (terjemahan), Jakarta: Penerbit EGC, hal. 4-6.

Li, Y., Schutte, R.J., Abu-Shakra, A., dan Reichert, W.M., 2005, "Protein array method for assessing in vitro biomaterials-induced cytokine expression", Biomaterials, 26(10), hal. 1081-1085.

Luyn, M.J.A.v., Plantinga, J.A., Brouwer, L.A., Khouw, I.M.S.L., Leij, L.F.M.H.d., dan Wachem, P.B.v., 2001, "Repetitive subcutaneous implantation of different types of (biodegradable) biomaterials alters the foreign body reaction. Biomaterials, 22(11), hal. 1385-1391.

Ma'ruf, T., Siswomihardjo, W., Soesatyo, M.H.N.E., dan Tontowi, A.E., 2013, "Polyvinyl Alcohol - Hydroxyapatite Composite Reinforced with Catgut Fibers as Biodegradable Bone Plates", Prosiding pada International Conference on Instrumentation, 
Communication, Information Technology and Biomedical Engineering, Bandung, Indonesia.

Mazzonetto, R.,Paza, A.O., danSpagnoli, D.B., 2004, "A retrospective evaluation of rigid fixation in orthognathic surgery using a biodegradable selfreinforced (70L:30DL) polylactide", Int J Oral Maxillofac Surg., 33, hal. 664-669.

Mitchell, R.N., dan Cotran, R.S., 2003, Acute and chronic inflammation, dalam Robbins Basic Pathology, $7^{\text {th }}$ ed., Diedit oleh S.L. Robbins, dan V. Kumar, Philadelphia: Elsevier Saunders, hal. 33-59.

Muno, D., Kominami, E., dan Mizuochi, T., 2000, "Generation of both MHC class I- and class II-restricted antigenic peptides from exogenously added ovalbumin in murine phagosomes", FEBS Lett., 478(1-2), hal. 178-182.

Navia, J.M., 1997, Animal Modelsin Dental Research, USA: The Univ. of Alabama Press.

Ngatijan, 2006, Toksikologi: Racun, Keracunan, dan Terapi Keracunan, Bagian Farmakologi dan Toksikologi Fakultas Kedokteran UGM, Yogyakarta, hal. 6-44.

Nicholson, J.W., 2002, The Chemistry of Medical and Dental Materials, R.S.C, Cambridge, hal. 186-221.

Pan, Y.S., Xiong, D.S., dan Ma, R.Y., 2007, "A study on the friction properties of poly(vinyl alcohol) hydrogel as articular cartilage against titanium alloy", Wear, 262, hal. 1021-1025.

Peppas, N.A., dan Merrill, E.W., 1977, "Development of semicrystalline poly(vinyl alcohol) hydrogels for biomedical application", J Biomed Mater Res., 11, hal. 423-434.

Price, S.A., dan Wilson, L.M., 2005,
Patofisiologi Konsep Klinis Proses-proses Penyakit, edisi 6, Diterjemahkan oleh B.U. Pendit dkk., Jakarta: EGC, hal 57-71.

Pruett, S.B., 2003, "Stress and the immune system", Pathophysiology, 9(3), hal. 133-153.

Robbins, S.L., dan Anggel, M., 1976, Basic Pathology, $2^{\text {nd }}$ ed., Philadelphia: W.B. Saunders Company, hal. 21-44.

Robbins, S.L., dan Kumar, V., 1995, Buku ajar patologi I, $4^{\text {th }}$ ed., (terjemahan), Jakarta: EGC.

Roitt, I., Brostoff, J., dan Male, D., 1998, Immunology $5^{\text {th }}$ ed., London: Mosby International Limited, hal. 302-348.

Scher, N., Poe, D., Kuchmir, F., Reft, C., Weichselbaum, R. dan Panje, W.R.,1988, "Radiotherapy of the selected mandible following stainless steel plate fixation", Laryngoscope, 98, hal. 561-563.

Schliephake, H., Lehmann, H., Kunz, U., dan Schmelzeisen, R,. 1993, "Ultrastructural findings in soft tissues adjacent to titanium plates used in jaw fracture treatment", Int J Oral Maxillofac Surg., 22, hal. 20-25.

Shayne, C.G., dan Christopher, P.C., 1998, Acute Toxicology Testing, $2^{\text {nd }}$ ed., London: Academic Press, hal. 244255.

Sirica, A.E. 1996, Cellular and Molecular Pathogenesis, Philadelphia: Lippincott-Raven.

Stammen, S., Williams, J.A., dan Ku, D.N., 2001, "Mechanical properties of a novel PVA hydrogel in shear and unconfined compression", Biomaterials, 22, hal. 799-806.

Suchanek, W., dan Yoshimura, M.J., 1998, "Processing and properties of hydroxyapatite based biomaterials for use as hard tissue replacement 


$$
\text { implants", Mater Res., 13, hal. } 94 .
$$

Suciu, A.N., Iwatsubo, T., dan Matsuda, M., 2004, "A study upon durability of the artificial knee joint with PVA hydrogel cartilage", JSME 47(1) Part C, hal. 199-208.

Sudiono, J., Kurniadi, B., Hendrawan, A., dan Djimantoro, B., 2003, Ilmu Patologi, Diterjemahkan oleh J.Sudiono dan L. Yuwono, Jakarta: EGC, hal 81-96.

Sudrajat, I., 2005, Skor Histologi CD8+ Pada Proses Penyembuhan Luka Tikus wistar, Tesis: Universitas Diponogoro Semarang.
Yerit, K.C., Enislidis, G., Schoppe,r C., Turhani, D., Wanschitz, F., dan Wagner, A., 2002, "Fixation of mandibular fractures with biodegradable plate and screw", Oral Surg Oral Med Oral Pathol Oral Radiol Endod, 94, hal. 294-300.

Wahl, D.A., dan Czernuszka, J.T., 2006, "Collagen-hydroxyapatite composites for hard tissue repair", European cells and Materials, 11, hal. 43-56.

Williams, D., 1990, Concise Encyclopedia of Medical and Dental Materials, United Kingdom: Pergamon Press, hal. 8793. 